DE

M E D I C I N A

T R O P I C A L

$\mathrm{DE}$

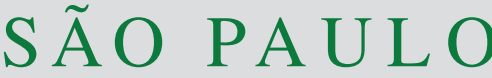

JOURNAL OF THE SÃO PAULO INSTITUTE OF TROPICAL MEDICINE

'Universidade de Brasília, Faculdade de Medicina, Laboratório Interdisciplinar de Biociências, Brasília, Distrito Federal, Brazil

2Secretaria de Saúde de Brasília, Instituto de Diagnósticos, Brasília, Distrito Federal, Brazil

${ }^{3}$ Universidade de Brasília, Faculdade de Medicina, Núcleo de Medicina Tropical, Brasília, Distrito Federal, Brazil

${ }^{4}$ Instituto de Avaliação de Tecnologias em Saúde, Brasília, Distrito Federal, Brazil

Correspondence to: Nadjar Nitz Universidade de Brasília, Faculdade de Medicina, Laboratório Interdisciplinar de Biociências, Campus Darcy Ribeiro, Asa Norte, CEP 70910-900, Brasília, DF, Brazil. Tel: +55 61 98177-0308

E-mail: nadjarnitz@gmail.com

Received: 14 July 2020

Accepted: 23 September 2020

\section{Seroprevalence of Trypanosoma cruzi in pregnant women in Midwest Brazil: an evaluation of congenital transmission}

\author{
Tayane Nobre ${ }^{\circledR 1,2}$, Silvio Fonseca ${ }^{\circledR 2,3}$, Raquel Medeiros ${ }^{\circledR 2}$, Mariana Hecht ${ }^{\circledR 1}$,
} Luciana Hagström ${ }^{\circledR}$, Maria R. Fernandes ${ }^{\circledR 3,4}$, Nadjar Nitz ${ }^{\oplus 1}$

\section{ABSTRACT}

Chagas disease (CD) is caused by the protozoan Trypanosoma cruzi and it is mainly acquired through the vector route, however, blood transfusion and congenital transmission are implicated in the spread of the illness worldwide. The congenital route can occur at any stage of pregnancy and its frequency varies. In the Federal District, in Brazil, the frequency of $T$. cruzi infection in pregnant women and their offspring has not been updated. Thus, the aim of this study was to estimate the prevalence of $T$. cruzi infection in pregnant women and the rate of congenital transmission in the Federal District. A cross-sectional study was conducted to estimate the seroprevalence of T. cruzi from 2014 to 2016 in the population of pregnant women attended by the public health service throughout the Federal District and a descriptive cohort for the evaluation of congenital transmission. During the study, prenatal data of 98,895 women were consulted and pregnant women registered in 2016, presenting with positive T. cruzi serology, were part of the descriptive cohort. The estimated prevalence of $T$. cruzi infection in the three years was $0.19 \%$ and the congenital transmission rate was $1 / 40(2.5 \%)$. Our results have shown that, although the main routes of transmission of CD have been interrupted, there is still a risk of congenital transmission in the Federal District. This present study highlights the need for the continuous implementation of a screening program for pregnant women and timely treatment of infected newborns and children.

KEYWORDS: Chagas disease. Congenital transmission. Pregnant Women. Trypanosoma cruzi. Screening program.

\section{INTRODUCTION}

Chagas disease (CD) is caused by the protozoan parasite Trypanosoma cruzi and is considered a neglected tropical disease that affects about 6 to 7 million people worldwide ${ }^{1}$. In recent years, $\mathrm{CD}$ has emerged as an important global health problem due to migratory flows spreading the infection to non-endemic countries ${ }^{2}$. The main route of $\mathrm{CD}$ acquisition is through vector transmission, but there are other important routes such as through blood transfusion, consumption of contaminated food and congenital transmission ${ }^{3}$. In Brazil, effective measures were implemented to control the vector and transfusion transmission pathways, which led to a substantial reduction of new cases of $\mathrm{CD}^{4,5}$. However, there are millions of chronic cases that need attention from health services and public policies and this is a persisting challenge. This group includes women of childbearing age who can transmit the parasite vertically to their offspring ${ }^{4,6}$.

The transmission of $T$. cruzi from infected mothers to their fetuses can occur at any stage of pregnancy and most cases of congenital $\mathrm{CD}$ are asymptomatic in 
newborns ${ }^{7}$. The frequency of congenital transmission varies according to the evaluated region and the diagnostic tests used. In the American continent, the rate is of $2 \%$, but in countries like Argentina, Bolivia and Mexico, it varies between $5 \%$ and $7 \% 8$. In Brazil, it is around $1.7 \%$.

The diagnosis of congenital transmission of T. cruzi begins with the detection of infection in pregnant women and is thereafter confirmed through the confirmation of the infection in the newborns of positive mothers. The diagnostic tests in pregnant women should be performed as soon as the pregnancy is confirmed, as any newborn of an infected mother is at risk of infection by the parasite ${ }^{10}$. Early diagnosis and treatment of the newborn are essential to reduce the risk of developing disabling chronic conditions ${ }^{11}$. Due to the non-inclusion of $T$. cruzi diagnosis in the prenatal serological screening in several Brazilian regions, asymptomatic cases of congenital transmission may be underestimated and consequently neglected ${ }^{12}$.

The congenital transmission is a form of continuity and maintenance of $\mathrm{CD}$. Therefore, knowing the frequency of this condition in women of childbearing age and newborns is extremely important as these data are scarce and outdated in the Federal District $(\mathrm{FD})^{13}$. The aim of this study was to estimate the prevalence of $T$. cruzi infection in pregnant women attended by the public service of the FD and to determine the rate of congenital CD transmission.

\section{MATERIALS AND METHODS}

\section{Study design and population}

The study was conducted in the FD, which is the seat of the government where the Brazilian capital is situated. It is located in the Midwest of the country with an estimated population of 3,015,268 inhabitants ${ }^{14}$. A cross-sectional study was carried out in the first phase of the study. Data registered in the information system of the Diagnostic Institute of Brasília (FD Health Secretariat), the institution responsible for prenatal screening tests, were consulted for the extraction of information on pregnant women to enable the seroprevalence estimate. The population was composed of all pregnant women attended by the public health system in the prenatal care throughout the FD, between 2014 and 2016, totaling 98,895 pregnant women. In the second phase, women registered in 2016 who tested positive during the prenatal care were invited through a phone call to participate in a descriptive cohort with the objective of evaluating the congenital transmission. A questionnaire on the demographic profile, place of birth, housing characteristics, socioeconomic and clinical data, knowledge, attitudes and practices regarding $\mathrm{CD}$ was applied to the women who had formally accepted to participate. In addition, blood samples were collected from mothers and their newborns. Newborns' samples were collected after birth and after nine months of age. The samples were submitted to parasitological and serological tests. The application of the questionnaire and the collection of samples occurred between September 2017 and June 2018.

\section{Parasitological and serological diagnosis}

The direct search of T. cruzi was carried out to evaluate the presence of the parasite in peripheral blood samples of mothers and newborns/ children. Samples were evaluated in serological tests for the detection of IgG and IgM antibodies anti-T. cruzi by an Immunoenzyme assay (ELISA) and an Indirect Hemagglutination test (HAI). The ELISA was performed with the kit GOLD ELISA CHAGAS (REM, Sao Paulo, Brazil) following the manufacturer's recommendations. The HAI test was performed according to the CHAGATEST kit protocol (Wiener, Rosario, Argentina).

\section{Statistical analysis}

The collected data were entered into an Excel spreadsheet and analyzed by the SPSS software, version 22 (SPSS Inc., Chicago, IL, USA). The descriptive analysis of the results determined the absolute and relative frequencies calculated for the categorical variables.

\section{Ethical approval}

The study was approved by the Research Ethics Committee of the Faculty of Medicine/UnB (CAAE $\mathrm{N}^{\circ}$ 67968717.5.0000.5558/2017). Informed consent was obtained from all the participants.

\section{RESULTS}

A total of 98,895 pregnant women were tested during the prenatal care of whom $188(0.19 \%)$ were positive for CD. The prevalence of T. cruzi infection in 2014, 2015 and 2016 was $0.19 \%(52 / 25,871), 0.21 \%(74 / 35,790)$ and $0.17 \%$ $(62 / 37,234)$ respectively. Most pregnant women were in the 30 to 39 years age group (Table 1 ).

The geographic distribution of pregnant women in the FD was evaluated by the location of the prenatal care unit in the Administrative Region (AR). In the three years, Ceilandia was the AR that tracked the largest number of pregnant women, a total of 17,878 individuals, corresponding to most of the positive cases, $15.43 \%$ (29/188) (Figure 1). 
Table 1 - Distribution by age group of T. cruzi-seropositive pregnant women attended by public health services in 2014, 2015 and 2016. Federal District, Brazil.

\begin{tabular}{lccc}
\hline Year & Age group & $\mathrm{n}$ & $\%$ \\
\hline \multirow{3}{*}{2014} & $<20$ & $1 / 52$ & 1.9 \\
& $20-29$ & $10 / 52$ & 19.2 \\
& $30-39$ & $25 / 52$ & 48.1 \\
& $\geq 40$ & $16 / 52$ & 30.8 \\
\hline \multirow{2}{*}{2015} & $<20$ & $2 / 74$ & 2.7 \\
& $20-29$ & $9 / 74$ & 12.1 \\
& $30-39$ & $47 / 74$ & 63,6 \\
& $\geq 40$ & $14 / 74$ & 18.9 \\
& Not reported & $2 / 74$ & 2.7 \\
\hline \multirow{4}{*}{016} & $<20$ & $1 / 62$ & 1.6 \\
& $20-29$ & $9 / 62$ & 14.5 \\
& $30-39$ & $42 / 62$ & 67.7 \\
& $\geq 40$ & $10 / 62$ & 16.1 \\
\hline
\end{tabular}

The descriptive cohort study was conducted with (42/62) of mothers who tested positive in 2016 and their 43 babies. One woman died due to complications of CD and was excluded from the study. Concerning the housing characteristics, $50 \%$ of the interviewees reported having lived most of their lives in rural areas where there was no asphalt, treated water, sewage and garbage collection. For the socioeconomic variables, approximately $38 \%$ (16/42) had as profession/ occupation: "home secretary" (domestic worker), and (22/42) did not work. Most of the families income ranged from 1 to 3 minimum wages. Regarding the demographic variables, the majority came from Bahia State, Northeast of Brazil (Table 2).

In relation to knowledge, attitudes and practices regarding $\mathrm{CD}$, more than $80 \%$ reported having knowledge about the disease and they knew how the disease can be acquired. However, the degree of uncertainty on transmission pathways such as blood transfusion/ organ donation and whether the disease could be acquired through the contact with a sick person was approximately $33 \%$ each. The majority stated that they had knowledge about the triatomine, and when questioned on the contact with the insect vector (28/42-66.7\%) responded positively and (7/42- $16.7 \%$ ) admitted that they had already been bitten by triatomines. Regarding the conduct when the vector is found in the home environment, more than $70 \%$ confirmed to have already killed the insect immediately after its detection.

Regarding the knowledge on the positivity to $T$. cruzi infection, $(28 / 42-66.7 \%)$ said that they became aware

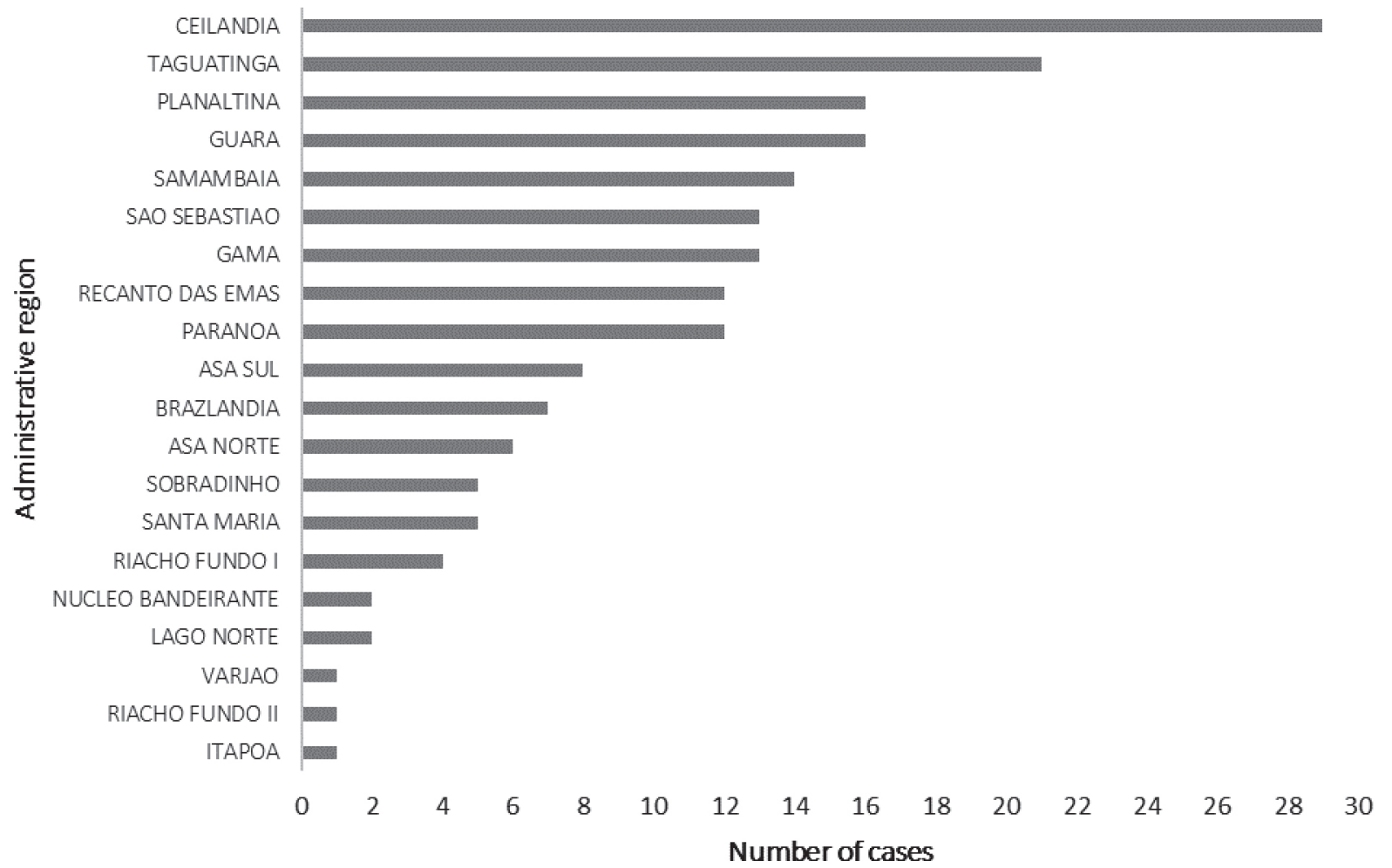

Figure 1 - Distribution of the number of seropositive cases by administrative region in the Federal District, Brazil, in 2014,2015 and 2016. 
Table 2 - Distribution of cases of T. cruzi-seropositive mothers according to demographics, socioeconomic data and educational level. Federal District, 2016.

\begin{tabular}{lcc}
\hline Data & (n) & $\%$ \\
\hline Federated unit of birth & & \\
Distrito Federal/ Goias & 4 & 9.5 \\
Para/Pernambuco/ Piaui & 4 & 9.5 \\
Minas Gerais & 4 & 9.5 \\
Maranhao & 5 & 11.9 \\
Bahia & 25 & 59.6 \\
Educational level & & \\
Elementary school & 17 & 40.4 \\
High school & 18 & 42.9 \\
College & 7 & 16.7 \\
Familiar income (in minimum wages) & & \\
Up to 1 (R $\$ 937.00)$ & 5 & 11.8 \\
From 1 to $3(\mathrm{R} \$ 937.00$ to $\mathrm{R} \$ 2,811.00)$ & 22 & 52.4 \\
From 3 to 6 ( $\mathrm{R} \$ 2,811.00$ to $\mathrm{R} \$ 5,622.00)$ & 9 & 21.4 \\
From 6 to $9(\mathrm{R} \$ 5,622.00$ to $\mathrm{R} \$ 8,433.00)$ & 2 & 4.8 \\
From 9 a $12(\mathrm{R} \$ 8,433.00$ to $\mathrm{R} \$ 11,244.00)$ & 2 & 4.8 \\
More than $12($ more than $\mathrm{R} \$ 11,244.00)$ & 1 & 2.4 \\
Do not know & 1 & 2.4 \\
\hline Total & 42 & 100 \\
\hline
\end{tabular}

during the prenatal care in 2016. Among the interviewees who already knew about the positivity, $50 \%$ were aware of the situation before the prenatal care. The mothers who said that they knew or suspected the possible route of infection (13/15) stated that it may have occurred due to the bite of the insect vector and (4/42- 9.5\%) had already received blood transfusions. In respect to the clinical signs that could be related to $\mathrm{CD}$, the most common complaints were: tiredness, tachycardia, arrhythmia and constipation. Most mothers with CD symptoms did not have or had any type of medical follow-up and around $45 \%$ received specific care in the private sector. Concerning the family history of $\mathrm{CD}, 69 \%$ responded positively. The results of the interviews are summarized in Table 3.

In relation to the seroprevalence in newborns, 40/43 (93\%) had the mother's authorization for the blood collection. Of these, $97.5 \%$ (39/40) were negative, with a single positive case confirming positive serology after 9 months of age. The child was treated at the University Hospital of Brasilia, where the infant was evaluated and received antiparasitic treatment for 60 days.

The direct parasitological test showed negative results for all tested samples of seropositive mothers and their children.

\section{DISCUSSION}

Similar studies performed in Brazil have shown that the frequency of $\mathrm{CD}$ infection in pregnant women in Brazil is between 0.1 and $0.5 \%^{15-17}$. However, the prevalence found in our study is lower when compared to other countries in Latin America, whose rates range from 3.2 to $23.6 \%{ }^{18-21}$. The high frequency found in pregnant women with more than 32 years of age is similar to other findings that have found age as a factor associated with the risk of infection by T.cruzi due to the accumulated exposure over the years $^{18,22}$.

The locality with the highest number of pregnant women screened and seropositive for T. cruzi was Ceilandia, the most populous region with a low per capita income in the $\mathrm{FD}^{23}$. Most immigrants in the FD $(52.15 \%)$ came from the Northeast of Brazil and Ceilandia is home to the majority ${ }^{24}$. The level of education of the interviewees is higher than the general population of the FD, however, the family income was below the average and most are participants were unemployed ${ }^{24}$. The participants had lived or still live in places without asphalt, basic sanitation, and referred contact with cob walls or similar structures, supporting that seropositivity is more frequent among the less socially and economically favored population ${ }^{25}$.

The main knowledge of mothers about $\mathrm{CD}$ was related to vector transmission. This is justifiable due to the contact with these insects during childhood. Regarding the lack of knowledge about $\mathrm{CD}$ symptoms, this may be related to the fact that most are asymptomatic. This lack of symptoms makes the search for health services less common and may be related to the fact that most of them become aware of their seropositivity only in the prenatal care. In addition, the scarcity of guidelines and the lack of information on the risk of congenital transmission by health professionals has been reported. These perceptions were also pointed out by Bolivian immigrants in $\operatorname{Spain}^{26}$. We observed that the interviewees did not know how to proceed correctly if they find the insect vector in the home environment. The knowledge of the community on how to behave if they find triatomines is extremely important and should be articulated to the practices of community collaboration with the surveillance and control agencies ${ }^{27}$.

In respect to the investigation of congenital transmission, our study showed $1 / 40$ (2.5\%) of seropositivity, corresponding to a single case in which the infant remained positive for antibodies against $T$. cruzi after nine months ofage. Given the exclusion of other routes of transmission and the age of the infant, it was possible to affirm that there was a case of congenital transmission. The frequency found remained within the national range ${ }^{28}$, which varied from 0 to $5.2 \%$. 
Table 3 - Distribution of cases of T. cruzi-seropositive mothers according to the knowledge of Chagas disease, its vector and clinical data. Federal District, 2016.

\begin{tabular}{|c|c|c|}
\hline Question & $(n)$ & $\%$ \\
\hline \multicolumn{3}{|l|}{ Knowledge of CD } \\
\hline Yes & $34 / 42$ & 81 \\
\hline No/Not sure & $8 / 42$ & 19 \\
\hline \multicolumn{3}{|c|}{ Knowledge about the transmission of CD } \\
\hline Yes & $35 / 42$ & 83.3 \\
\hline No & $5 / 42$ & 11.9 \\
\hline Not sure & $2 / 42$ & 4.8 \\
\hline \multicolumn{3}{|l|}{ Knowledge about the vector } \\
\hline Yes & $36 / 37$ & 97.3 \\
\hline No & $1 / 37$ & 2.7 \\
\hline \multicolumn{3}{|c|}{ Knowledge about congenital transmission } \\
\hline Yes & $20 / 37$ & 54.1 \\
\hline No & $7 / 37$ & 18.9 \\
\hline Not sure & $10 / 37$ & 27 \\
\hline \multicolumn{3}{|c|}{ Knowledge about CD symptoms } \\
\hline Yes & $15 / 42$ & 35.7 \\
\hline No & $15 / 42$ & 35.7 \\
\hline Not sure & $12 / 42$ & 28.6 \\
\hline \multicolumn{3}{|l|}{ Knowledge about CD treatment } \\
\hline Yes & $24 / 42$ & 57.1 \\
\hline No & $10 / 42$ & 23.8 \\
\hline Not sure & $8 / 42$ & 19.1 \\
\hline \multicolumn{3}{|l|}{ Recognize the vector insect } \\
\hline Yes & $35 / 42$ & 83.3 \\
\hline No & $5 / 42$ & 11.9 \\
\hline Not sure & $2 / 42$ & 4.8 \\
\hline \multicolumn{3}{|c|}{ Had contact with the vector insect } \\
\hline Yes & $28 / 42$ & 66.7 \\
\hline No & $11 / 42$ & 26.2 \\
\hline Not sure/Do not remember & $3 / 42$ & 7.1 \\
\hline
\end{tabular}

The small number of mothers and babies evaluated can be considered a limitation of our study, as it was not possible to find all mothers due to the change of telephone numbers, home address or even moving to a different State. Studies performed with a larger sample can be more conclusive, however, it is worth mentioning that our study represents a first step in updating the data concerning the congenital transmission of CD in the FD, Brazil.

Better quality of life and prognosis of infected mothers in addition to timely treatment of congenital cases allowing high cure rates justify the efforts and the importance of prenatal screening programs. Serological screening for T. cruzi infection in the prenatal care has not yet been implemented at the national level. Consequently, due to the poor monitoring of pregnant women and their children especially in endemic regions, many cases of congenital transmission might be underreported and neglected in Brazil $^{12}$.

\begin{tabular}{|c|c|c|}
\hline Question & $(n)$ & $\%$ \\
\hline \multicolumn{3}{|l|}{ Sting by the insect vector } \\
\hline Yes & $7 / 42$ & 16.7 \\
\hline No & $5 / 42$ & 11.9 \\
\hline Don't remember & $15 / 42$ & 35.7 \\
\hline Do not know/Not sure & $15 / 42$ & 35.7 \\
\hline \multicolumn{3}{|l|}{ Conduct regarding the insect vector } \\
\hline Kill the insect & $30 / 42$ & 71.4 \\
\hline $\begin{array}{l}\text { Capture and search for an agency } \\
\text { responsible for identification }\end{array}$ & $8 / 42$ & 19 \\
\hline Directly notify health center/health agent & $2 / 42$ & 4.8 \\
\hline Do not know/Others & $2 / 42$ & 4.8 \\
\hline \multicolumn{3}{|c|}{ Knew the positive result for CD before prenatal care } \\
\hline Yes & $14 / 42$ & 33.3 \\
\hline No & $28 / 42$ & 66.7 \\
\hline \multicolumn{3}{|l|}{ Positive result knowledge } \\
\hline Blood donation & $2 / 14$ & 14.3 \\
\hline Routine tests & $5 / 14$ & 35.7 \\
\hline Prenatal care before & $7 / 14$ & 50 \\
\hline \multicolumn{3}{|l|}{ Clinical signs related to CD } \\
\hline Yes & $13 / 42$ & 31 \\
\hline No & $22 / 42$ & 52.3 \\
\hline Do not t know & $7 / 42$ & 16.7 \\
\hline \multicolumn{3}{|l|}{ Medical care to CD } \\
\hline Yes & $9 / 42$ & 21.4 \\
\hline No & $33 / 42$ & 78.6 \\
\hline \multicolumn{3}{|l|}{ CD drug treatment } \\
\hline Yes & $1 / 42$ & 2.4 \\
\hline No & $41 / 42$ & 97.6 \\
\hline
\end{tabular}

In conclusion, the prevalence of pregnant women with $T$. cruzi infection and the frequency of congenital transmission shown in the present study were similar to other reports in Brazil. Prenatal screening is extremely important for the knowledge of positive cases in pregnant women. It allowed the identification of a case of congenital CD transmission in the FD, Brazil, which would probably be undetected as the child was asymptomatic and was not monitored by the health service. Our results highlight the need for the continuous implementation of a screening program for pregnant women and timely treatment for newborns and infected children in Brazil.

\section{AUTHORS' CONTRIBUTIONS}

TN, NN and MRF designed and elaborated the study; $\mathrm{TN}, \mathrm{SF}$ and RM were responsible for sample collection and application of the questionnaires; TN, SF and RM 
performed serological and parasitological tests; TN, NN, $\mathrm{MH}, \mathrm{LH}$ and MRF analyzed the data; TN, LH, NN, and MRF contributed to the writing of the manuscript. All authors read and approved the final manuscript.

\section{CONFLICT OF INTERESTS}

None declared.

\section{FUNDING}

This study was financed in part by the Agency for Training Human Resources (CAPES), Ministry of Education, Brazil - Finance Code 001.

\section{REFERENCES}

1. World Health Organization. Chagas disease (American trypanosomiasis). [cited $2020 \mathrm{Sep} 23$ ]. Available from: https:// www.who.int/health-topics/chagas-disease\#tab=tab_1

2. Perez CJ, Lymbery AJ, Thompson RC. Reactivation of Chagas disease: implications for global health. Trends Parasitol. 2015;31:595-603.

3. Coura JR. Chagas disease: what is known and what is needed - a background article. Mem Inst Oswaldo Cruz. 2007;102 Suppl 1:113-22

4. Ferreira IL, Silva TP. Eliminação da transmissão da doença de Chagas pelo Triatoma infestans no Brasil: um fato histórico. Rev Soc Bras Med Trop. 2006;39:507-9.

5. Coura JR, Dias JC. Epidemiology, control and surveillance of Chagas disease: 100 years after its discovery. Mem Inst Oswaldo Cruz. 2009;104 Suppl 1:31-40.

6. Carlier Y, Sosa-Estani S, Luquetti AO, Buekens P. Congenital Chagas disease: an update. Mem Inst Oswaldo Cruz. 2015;110:363-8.

7. Cevallos AM, Hernández R. Chagas' disease: pregnancy and congenital transmission. Biomed Res Int. 2014;2014:401864.

8. Santana KH, Oliveira LG, Castro DB, Pereira M. Epidemiology of Chagas disease in pregnant women and congenital transmission of Trypanosoma cruzi in the Americas: systematic review and meta-analysis. Trop Med Int Heal. 2020;25:752-63.

9. Howard EJ, Xiong X, Carlier Y, Sosa-Estani S, Buekens P. Frequency of the congenital transmission of Trypanosoma cruzi: a systematic review and meta-analysis. BJOG. 2014;121:22-33.

10. CarlierY, Truyens C. Maternal-fetal transmission of Trypanosoma cruzi. In: Telleria J, Tibayrenc M, editors. American Trypanosomiasis: one hundred years of research. Amsterdam: Elsevier; 2010. p.539-81.

11. Francisco-González L, Rubio-San-Simón A, González-Tomé MI, Manzanares A, Epalza C, Del Mar Santos M, et al. Congenital transmission of Chagas disease in a non-endemic area, is an early diagnosis possible? PLoS One. 2019;14:e0218491.

12. Dias N, Carvalho B, Nitz N, Hagström L, Vital T, Hecht M. Congenital Chagas disease: alert of research negligence. Rev Soc Bras Med Trop. 2019;52:e20180069.

13. Medina-Lopes MD. Transmissâo materno-infantil da doenca de Chagas: incidência da forma congênita e da adquirida durante aleitamento. Rev Soc Bras Med Trop. 1992;25 Supl 3:99.

14. Instituto Brasileiro de Geografia e Estatística. Brasil, Distrito Federal. [cited 2020 Sep 23]. Available from: https://cidades. ibge.gov.br/brasil/df/panorama

15. Figueiró-Filho EA, Senefonte FR, Lopes AH, Morais OO, Souza Júnior VG, Maia TL, et al. Freqüência das infecções pelo HIV-1, rubéola, sífilis, toxoplasmose, citomegalovírus, herpes simples, hepatite B, hepatite C, doença de Chagas e HTLV I/ II em gestantes, do Estado de Mato Grosso do Sul. Rev Soc Bras Med Trop. 2007;40:181-7.

16. Gontijo ED, Andrade GM, Santos SE, Galvão LM, Moreira EF, Pinto FS, et al. Triagem neonatal da infecção pelo Trypanosoma cruzi em Minas Gerais, Brasil: transmissão congênita e mapeamento das áreas endêmicas. Epidemiol Serv Saude. 2009; 18:243-54.

17. Gomes Filho C, Macedo Filho JV, Gomes MM, Luquetti AO. Triagem pré-natal ampliada: teste da mamãe. Vita Sanitas. 2009;3:101-9.

18. Castellanos-Domínguez YZ, Cucunubá ZM, Orozco LC, Valencia-Hernández CA, León CM, Florez AC, et al. Risk factors associated with Chagas disease in pregnant women in Santander, a highly endemic Colombian area. Trop Med Int Health. 2016;21:140-8

19. Salas Clavijo NA, Postigo JR, Schneider D, Santalla JA, Brutus L, Chippaux JP. Prevalence of Chagas disease in pregnant women and incidence of congenital transmission in Santa Cruz de la Sierra, Bolivia. Acta Trop. 2012;124:87-91.

20. Carrera Vargas C, Narváez AO, Muzzio Aroca J, Shiguango G, Robles LM, Herrera C, et al. Seroprevalence of Trypanosoma cruzi infection in schoolchildren and in pregnant women from an Amazonian Region in Orellana Province, Ecuador. Am J Trop Med Hyg. 2015;93:774-8.

21. Montes-Rincón LM, Galaviz-Silva L, González-Bravo FE, Molina-Garza ZJ. Trypanosoma cruzi seroprevalence in pregnant women and screening by PCR and microhaematocrit in newborns from Guanajuato, Mexico. Acta Trop. 2016;164:100-6.

22. Cucunubá ZM, Flórez AC, Cárdenas A, Pavía P, Montilla M, Aldana R, et al. Prevalence and risk factors for Chagas disease in pregnant women in Casanare, Colombia. Am J Trop Med Hyg. 2012;87:837-42.

23. Jatobá SU. Densidades urbanas nas regiões administrativas do distrito federal. Brasília, DF: CODEPLAN; 2017. [cited 2020 Set 23] Available from: http://www.codeplan.df.gov.br/ 
wp-content/uploads/2018/02/TD_22_Densidades_Urbanas_ nas_Regiões_Administrativas_DF.pdf

24. Brasil. Distrito Federal. Companhia de Planejamento do Distrito Federal. Pesquisa distrital por amostra de domicílios: PDAD/ DF-2015. Brasília, DF: CODEPLAN; 2016. [cited 2020 Sep 23]. Available from: http://www.codeplan.df.gov.br/wpcontent/uploads/2018/02/PDAD-Distrito-Federal-1.pdf

25. Cardoso DR, Reis LM, Sousa RF, Nascimento EF, Santos JP, Carvalho-Costa FA, et al. Chagasic infection among blood donors in Brazil: an integrative review. Hematol Transfus Cell Ther. 2018;40:283-91.
26. Blasco-Hernández T, García-San Miguel L, Navaza B, Navarro M, Benito A. Knowledge and experiences of Chagas disease in Bolivian women living in Spain: a qualitative study. Glob Health Action. 2016;9:30201.

27. Maeda MH, Gurgel-Gonçalves R. Conhecimentos e práticas de moradores do Distrito Federal, Brasil, em relação à doença de Chagas e seus vetores. Rev Patol Trop. 2012;41:15-26.

28. Martins-Melo FR, Lima MS, Ramos Jr AN, Alencar CH, Heukelbach J. Systematic review: prevalence of Chagas disease in pregnant women and congenital transmission of Trypanosoma cruzi in Brazil: a systematic review and metaanalysis. Trop Med Int Health. 2014;19:943-57. 